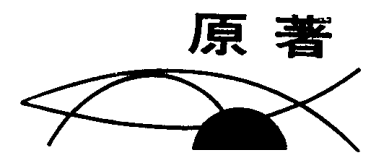

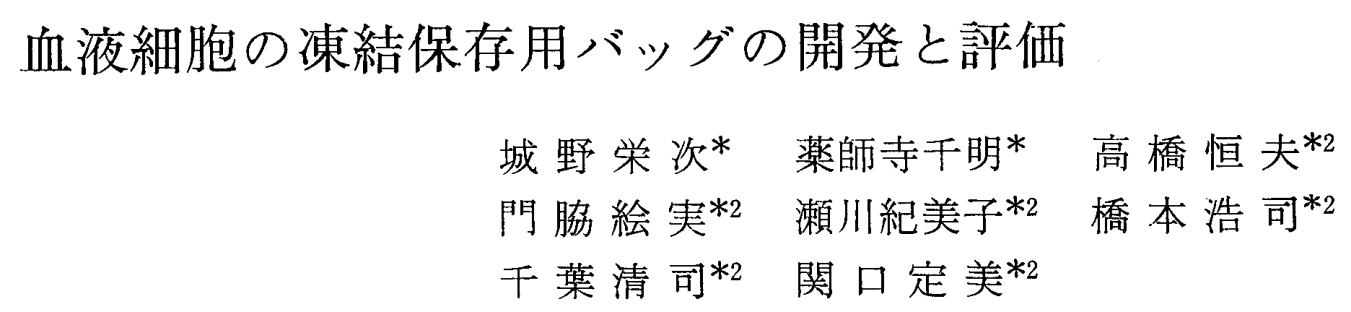

\title{
Development and Evaluation of a Freezing-stable Bag for Cryopreservation of Blood Cells
}

\author{
Eiji Kino*1, Chiaki Yakushiji*1, Tsuneo A. Takahashi*2, \\ Emi Kadowaki*2, Kimiko Segawa*2, Hiroshi Hashimoto*2, \\ Seiji Chiba*2 and Sadayoshi Sekiguchi*2 \\ *1 Kawasumi Laboratories Inc., \\ 3-28-15, Minamiohi, Shinagawa-ku, Tokyo 140, Japan \\ *2Hokkaido Red Cross Blood Center, \\ 2-2, Yamanote, Nishi-ku, Sapporo 063, Japan
}

\begin{abstract}
Cryopreservation is a method used to store blood cells for a long period without loss of viability and functions. However, the method is rather limited because the procedures of freezing and thawing, and removal of cryoprotectants are complicated. In addition, it requires an expensive programming freezer and special freezing bags which do not break at low temperature.

In this study, we developed a new freezing bag (KFB : Kawasumi Freezing Bag) which is made of laminated plastic composed of fluoride and polyolefin.

The tensile strength and elongation percentage at break and gas permeability of laminated plastic sheet were examined in accord with Japan Industrial Standard. The tensile strength at $-80^{\circ} \mathrm{C}$ and the gas permeability of laminated plastic sheet were almost equal to those of a polyvinyl chloride (PVC) sheet. However, the elongation percentage of laminated plastic sheet was twice as much as the PVC sheet at $-80^{\circ} \mathrm{C}$.

Platelets, red cells and peripheral blood stem cells were frozen in the newly developed freezing bags with their standard procedures. Platelets and peripheral blood stem cells were stored in liquid nitrogen, and red cells were stored at $-80^{\circ} \mathrm{C}$. There were no significant differences in the numerical recovery and the overall functions between cells frozen in the new freezing bag and the conventional bags (PVC or ethylene vinyl acetate). The freezing bags did not break in liquid nitrogen.

These results suggest that the freezing bag developed in this study is useful for cryopreservation of blood cells in liquid nitrogen.

*川澄化学工業株式会社

*2北海道赤十字血液センター

（原稿受付：1994年10月17日）
\end{abstract}




\section{はじめに}

血液細胞成分の凍結保存は, 液状保存に比較 乙長期間の保存を可能にするが，凍結・融解操 作が繁雑であり，さらに特殊なバッグ，凍害保 護液, 液体窒素, プログラミングフリーザーな どを必要とするためコスト高となる欠点がある. 特に凍結保存用バッグは外国メーカーによるも のが汪とんどであり，価格が高く，またその形 状は通常の血液バッグと異なり取り扱いに難点 がある，そこで我々は， $-80^{\circ} \mathrm{C}$ 以下の低温に も耐性を持つ素材からなる凍結保存専用の血液 バッグを開発し，これを用いて血液細胞の凍結 保存を行い，その有用性を評価したので報告す る.

\section{材料及び方法}

\section{1. 素材の物理的性質}

フッ素系樹脂とポリオレフィン (PO : polyolefin）系樹脂のラミネートフィルムを素材と した凍結保存バッグ (KFB : Kawasumi Freezing Bag, 川澄化学工業, 東京) を作成した。

室温及び $-80^{\circ} \mathrm{C}$ に打けるラミネートフィル 厶の強度, 伸率は, JIS (日本工業規格) K7127 プラスチックフィルム及びシートの引張試験方 法，また室温に扣けるガス透過率は，JIS K7126 プラスチックフィルム及びシートの気 体透過度試験方法に準じて測定した

引張強度試験は, ラミネートフィルムの最小 幅 $6 \mathrm{~mm}$, 標線間 $25 \mathrm{~mm}$ の 2 号ダンベル試験 牌を作成し，強度測定試験機（帛津オートグラ 7 AGS-100B，島津製作所，京都）によりク ロスヘッドスピード $200 \mathrm{~mm} / \mathrm{min}$ で試験片を 率引したときの破断強度及び破断時の伸率を室 温 $\left(25^{\circ} \mathrm{C}\right)$ 及び $-80^{\circ} \mathrm{C}$ にて測定した.

気体透過度試験は，ラミネートフィルムを $10 \times 10 \mathrm{~cm}$ の大きさに切り取り，ガス透過率測 定装置 (MC-1, 東洋精器製作所, 東京) にて 酸素及び炭酸ガスの透過率を測定した。ラミネ 一トフィルムの比較として, 従来血液バッグに 用いられているPVC (polyvinyl chloride) シートについても同様に室温と $-80^{\circ} \mathrm{C}$ に括け る破断強度, 伸率及び室温におけるガス透過率
を測定した。

\section{2. 凍結保存バッグの破損試験}

凍結保存バッグの耐低温性を調べる目的で, $600 \mathrm{ml}$ 容量の KFB バッグ (KFB-600), $\mathrm{PVC}$ バッグ (KBP-600: 川澄化学工業) 拈よ びポりオレフィン（PO : polyolefin）バッグ (KBP-600 CP : 川澄化学工業) に水を充填 し, 一 $40^{\circ} \mathrm{C}$ フリーザー中にて凍結した。 次いで液 体窒素中一浸漬して急冷し, 液体㗌素温度に凍 結したバッグを $40^{\circ} \mathrm{C}$ 水浴中で急速融解した.

この急激な温度变化を与光た場合のバッグ破損 の有無を確認した。 また，液体窒素温度で涷結 保存したバッグを液体窒素タンクから取り出し， 1 分以内に室温にて落差 $1 \mathrm{~m}$ でコンクリート床 に落下し，その衝撃による破損を調べた。

\section{3. 凍結保存バッグでの細胞保存性の評価}

$\mathrm{KFB}$ バッグを使用して, 血小板, 赤血球, 末梢血造血幹細胞の凍結保存を行い，PVC バ ッグをたは凍結保存用に従来使用されている EVA (ethylene vinyl acetate) バッグ (PL269 : Baxter, Deerfield, IL, USA) と細胞の 凍結保存性に与をる影響を比較検討した。

(1) 血小板凍結保存

成分採血装置. Fenwal CS-3000 Plus (Baxter）に上り健常人ょり採取した濃愿血小板 (PC: platelet concentrate) $60 \mathrm{ml}$ ずつ $\mathrm{KFB}$ バッグ (KFB-300), PVC バッグ (KBP -300) に分注し, 凍害保護液（15\% DMSO： dimethylsulfoxide/生理食塩液）を各々 $40 \mathrm{ml}$ 静かに攪拌しながら注入した後，プログラムフ リーザー (Cryo-Med, Mt. Clemens, MI, USA) にて $-1^{\circ} \mathrm{C} / \mathrm{min} て ゙-80^{\circ} \mathrm{C}$ で凍結 し, 液体窒素中で 1 週間保存した。融解は $37^{\circ} \mathrm{C}$ 水浴中で行い，15\% ACD (acid citrate dextrose) 添加血漿を融解 PC $100 \mathrm{ml}$ に対し $60 \mathrm{ml}$ 添加した後遠心 $\left(3,000 \mathrm{~g} \times 8 \mathrm{~min}, 10^{\circ} \mathrm{C}\right)$ し，上清血漿を除去してDMSOを除いた. 回 収した血小板ペレットは自己血漿に再浮遊し， $22^{\circ} \mathrm{C}$ で振璗保存した。

(2) 赤血球凍結保存

$200 \mathrm{ml}$ 全血由来の RC-MAP (MAP 加濃厚 赤血球，採血後 3 日目） 2 単位をプール して KFB バッグ (KFB-600), PVC バッグ 
(KBW-650：カワスミ洗浄バッグ) 各々に 2 分割 し，凍害保護液として $60 \%$ グリセリン（glycerin）を等容量ゆっくり混和しながら注入した。 次いで, $1,200 \mathrm{~g} \times 5 \mathrm{~min}$ で遠心し, 上清の余 分な凍害保護液を除去した後, $-80^{\circ} \mathrm{C}$ ディー プフリーザー中に静置して 2 週間凍結保存した. 融解は $37^{\circ} \mathrm{C}$ 水浴中にて急速に行い, 連続遠心 法にて脱グリセリン・洗浄を行っだ．最終的 に生理食塩液に浮遊して解凍赤血球浮遊液を得 た.

（3）末梢血造幹細胞凍結保存

$400 \mathrm{ml} \mathrm{ACD}$ 加全血由来のバフィーコート

(同じ血液型) 4 バッグをプールし，FicollPaque 比重遠心法にて単核球 (mononuclear cell) を分離し, RPMI 1640 (Life Technologies Inc., Grand Island, NY, USA) $28 \mathrm{ml}$ k 再浮遊した. 凍害保護液 $32 \mathrm{ml}$ (DMSO $6 \mathrm{ml}$, 血漿 $6 \mathrm{ml} ， 6 \%$ ヒドロキシェチルスターチ (HES)/生理食塩液 $20 \mathrm{ml}$ ) を加えて KFB バッグ, EVA バッグに分注してプログラムフ リーザーにて $-80^{\circ} \mathrm{C}$ ま泠却速度 $-1^{\circ} \mathrm{C} / \mathrm{min}$ で涷結した後, 液体窒素中で 1 週間保存した。 $40^{\circ} \mathrm{C}$ 水浴中にて急速に融解した後， $2 \% \mathrm{HES}$ 生理食塩液を加光遠心 $\left(400 \mathrm{~g} \times 10 \mathrm{~min}, 4^{\circ} \mathrm{C}\right)$ により上清を取り除き，凍害保護液を除去した。 最終的に $2 \% \mathrm{HES}$ 生理食塩液に再浮遊して 細胞を回収した。

\section{4. 凍結保存細胞の評価}

(1) 血小板の評価

凍結前後の $\mathrm{PC}$ の $\mathrm{pH}$, 血小板回収率, 平均血 小板容積 (MPV : mean platelet volume), 形態スコア及び血小板機能を以下の方法で測定 した.

$\mathrm{pH}$ は, サンプリング直後に $\mathrm{pH} /$ 血液ガス分 析装置 (Model 170，チバ・コーニング・ダイ アグノスティックス，東京）にて測定した. 血 小板機能は，PC を自己血漿で血小板濃度 3.5 $\times 10^{5} / \mu 1(\mathrm{pH} 7.4)$ に調製したPRP（platelet rich plasma，多血小板血漿）を検体として血 小板凝集能を血小板凝集能測定装置 (Hema Tracer 801, 二光バイオサイェンス，東京）にて 凝集惹起物質 ADP (adenosine diphosphate) 10, $20 \mu \mathrm{M}$ (Boehringer, Manheim, Germany)
またはコラーゲン $5,10 \mu \mathrm{g} / \mathrm{ml}$ (Nycomed Arzneimittel, München, Germany) およひび $\mathrm{ADP}$ とコラーゲン $(5 \mu \mathrm{M}+1 \mu \mathrm{g} / \mathrm{ml}, 5 \mu \mathrm{M}$ $+5 \mu \mathrm{g} / \mathrm{ml})$ の共存刺激による 10 分間の最大凝 集率を測定した。低浸透正ショック回復率 （\% HSR） は分光光度計にて検体 2 容に対して 1 容の蒸留水を加えた時の $610 \mathrm{~nm}$ に和ける 5 分間の透過率の変化を測定し，同じく生理食塩 液を加光た時の透過率から最大透過率比を算出 した。 また，PRPに 2.5\%グルタルアルデヒ ドを加㝋て固定した後, 形態スコアを位相差光 学顕微鏡にて観察した。

(2) 赤血球の評価

凍結前及び融解值後, 融解 24 時間後の性状に ついて赤血球回収率, 平均赤血球容積 $(\mathrm{MCV}$ : mean cell volume) を自動血球計数装置 (Coulter Counter S-Plus IV, Coulter Electronics, Hialeah, FL, USA) にて測定した.

2,3-DPG 及び ATP は, シグマ社製測定キ ット (Sigma, St. Louis, Mo, USA), 上清へ モグロビン量は, 遠心上清血漿を 3 波長吸光分 析法により測定した。赤血球浸透王抵抗性は CPC (coil planet centrifuge) 法により測定 した ${ }^{3)}$.

（3）末梢血造血幹細胞の評価

凍結融解前後に和ける細胞回収率, 生存率及 びュロニー形成細胞回収率を調べた. 細胞回収 率は, 凍結前後の細胞数を自動血球計数装置に て測定して求めた. 生存率は, 融解洗浄後の細 胞をトリパンブルーにて染色して求めた。コロ 二一形成細胞回収率は, 凍結前及び融解洗浄後 の細胞 (単核球) についてメチルセルロース法 にてコロニー形成細胞数を測定して求めた ${ }^{4)}$.

\section{5. 統計処理}

Student の paired t-test を行い, $\mathrm{p}<0.05$ を有意とした。

\section{結果}

\section{1. 素材の物理的性質}

引張強度試験に扮いて破断強度は PVC シー トとラミネートフィルムとも室温 $\left(25^{\circ} \mathrm{C}\right)$ より多低温 $\left(-80^{\circ} \mathrm{C}\right)$ に扣いて破断強度の上 昇がみられ， $-80^{\circ} \mathrm{C}$ では PVC シートが 981.2, 
表 1 凍結保存バッグ素材の物理的性質

\begin{tabular}{ccccc}
\hline & \multicolumn{2}{c}{ 室温 $\left(25^{\circ} \mathrm{C}\right)$} & \multicolumn{2}{c}{$-80^{\circ} \mathrm{C}$} \\
\cline { 2 - 5 } & PVC & KFB & PVC & KFB \\
\hline 破断強度 $\left(\mathrm{kg} \cdot \mathrm{f} / \mathrm{cm}^{2}\right)^{*}$ & 214.0 & 676.5 & 981.2 & 1074.0 \\
伸率 $(\%) *$ & 300.0 & 86.9 & 10.4 & 24.3 \\
\hline $\mathrm{O}_{2}$ 透過率 $\left(\mathrm{ml} / \mathrm{m}^{2} \cdot\right.$ day.atm)** & 590 & 550 & - & - \\
$\mathrm{CO}_{2}$ 透過率 $\left(\mathrm{ml} / \mathrm{m}^{2} \cdot \text { day.atm }\right)^{* *}$ & 3690 & 2370 & - & - \\
\hline & & & \multicolumn{3}{c}{ 各值は平均值 $(* \mathrm{n}=5, * * \mathrm{n}=2)$}
\end{tabular}

表 2 凍結保存バッグの破損試験

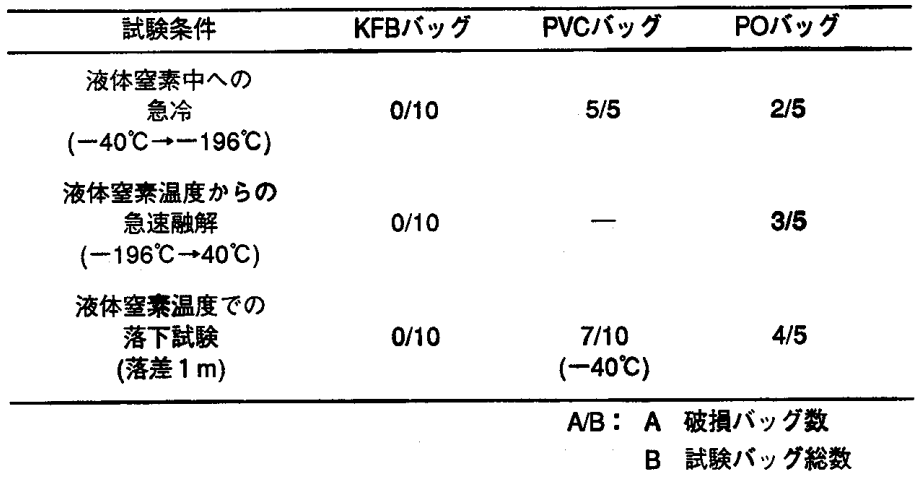

表 3 凍結前後における P C の性状

\begin{tabular}{|c|c|c|c|}
\hline 測定項目 & 凍結前 & 融解後PVCバッグ & 融解後KFBバッグ \\
\hline $\mathrm{pH}$ & $6.85 \pm 0.01$ & $6.99 \pm 0.03$ & $6.97 \pm 0.06$ \\
\hline 血小板数 $\left(\times 10^{11} / \mathrm{bag}\right)$ & $1.10 \pm 0.16$ & $0.96 \pm 0.16$ & $1.02 \pm 0.15$ \\
\hline 回収率 (\%) & - & $87.4 \pm 2.7$ & $92.5 \pm 3.0$ \\
\hline $\operatorname{MPV}(f \mid)$ & $7.34 \pm 1.85$ & $8.58 \pm 1.91$ & $8.38 \pm 1.95$ \\
\hline 形態スコア & $316.8 \pm 24.3$ & $210.8 \pm 14.1$ & $223.1 \pm 5.8$ \\
\hline$\% H S R$ & $75.0 \pm 3.7$ & $39.2 \pm 5.7$ & $37.4 \pm 8.3$ \\
\hline 凝集能* & $89.4 \pm 4.7$ & $45.5 \pm 3.3$ & $42.9 \pm 6.3$ \\
\hline
\end{tabular}

ラミネートシートが $1,074.0 \mathrm{~kg} \cdot \mathrm{f} / \mathrm{cm}^{2}$ と後

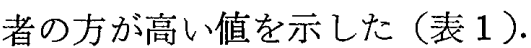

破断時の伸率は，PVC シートが室温に拈い て $300.0 \%$ であったが $-80^{\circ} \mathrm{C}$ では $10.4 \%$ と著しく低下した. 一方，ラミネートフィルム では低温下で柔軟性は低下するものの，その低 下は PVC シートに比べて少なかった。

ガス透過率に和いて， $\mathrm{KFB}$ シートは $\mathrm{O}_{2}$ 透 過率で PVC シートと注ぼ同等, $\mathrm{CO}_{2}$ は $\mathrm{PVC}$ シートより低い透過率を示した。

\section{2. 凍結保存バッグの破損試験}

各保存バッグの急冷, 急速融解, 衝撃に対す る耐性を調べた（表 2 ）.
PVC バッグ (KBP-600) は，水を充填して ー $40^{\circ} \mathrm{C}$ フリーザーにて凍結した後, 液体窒素 中に浸したところ，急激な温度変化に耐えず全 バッグ $(\mathrm{n}=5)$ 破損した。 また, $-40^{\circ} \mathrm{C}$ に 凍結保存したバッグを落下試験したところ，10 例中 7 例に破損がみられた。

$\mathrm{PO}$ バッグも急激な温度変化により 5 例中 3 例に破損を生じた，落下による衝撃では，5例 中 4 例のP O バッグが破損した.

$\mathrm{KFB}$ バッグでは，液体窒素による急冷，液 体窒素温度からの急速融解に拈いて，破損は 1 例もみられなかった $(\mathrm{n}=10)$. 落下による衝 撃に対しても破損は 1 例も又られなかった。 
表 4 凍結前後における赤血球の性状

\begin{tabular}{|c|c|c|c|c|c|c|}
\hline & \multicolumn{2}{|c|}{ 凍結前 } & \multicolumn{2}{|c|}{ 融解直後 } & \multicolumn{2}{|c|}{ 触解24hr後 } \\
\hline & PVC & KFB & PVC & KFB & PVC & $\mathrm{KFB}$ \\
\hline 赤血球数 (×10"1/bag) & $8.60 \pm 0.65$ & $9.03 \pm 1.14$ & $7.29 \pm 0.50$ & $7.79 \pm 0.80$ & $7.04 \pm 0.51$ & $7.52 \pm 0.76$ \\
\hline 回収率 (\%) & - & - & $84.9 \pm 2.1$ & $86.5 \pm 2.9$ & $81.9 \pm 2.9$ & $83.5 \pm 3.2$ \\
\hline$M C V$ (il) & \multicolumn{2}{|c|}{$86.9 \pm 5.2$} & $90.2 \pm 5.2$ & $90.4 \pm 5.4$ & $91.2 \pm 5.3$ & $91.4 \pm 5.6$ \\
\hline 2,3-DPG $(\mu \mathrm{mol} / \mathrm{gHb})$ & \multicolumn{2}{|c|}{$4.94 \pm 1.38$} & $4.81 \pm 1.19$ & $4.66 \pm 1.26$ & $3.43 \pm 1.18$ & $3.20 \pm 1.14$ \\
\hline ATP $(\mu \mathrm{mol} / \mathrm{gHb})$ & \multicolumn{2}{|c|}{$4.32 \pm 0.23$} & $4.80 \pm 0.17$ & $4.76 \pm 0.36$ & $4.66 \pm 0.26$ & $4.41 \pm 0.45$ \\
\hline ヘモグロビン含量 (g/dl) & \multicolumn{2}{|c|}{$17.8 \pm 1.5$} & $12.9 \pm 0.6$ & $13.9 \pm 1.6$ & $12.8 \pm 0.7$ & $13.9 \pm 1.6$ \\
\hline 上清へモグロヒンン量 $(\mathrm{mg} / \mathrm{dl})$ & \multicolumn{2}{|c|}{$13.7 \pm 5.5$} & $54.4 \pm 11.7$ & $38.5 \pm 11.7$ & $161.9 \pm 35.6$ & $172.7 \pm 60.3$ \\
\hline \multicolumn{7}{|c|}{ 赤血球湜透任抵抗性 (mOsm/kg) } \\
\hline 溶血開始点 & \multicolumn{2}{|c|}{$110 \pm 0$} & $150 \pm 0$ & $150 \pm 0$ & $150 \pm 0$ & $150 \pm 0$ \\
\hline 最大溶血点 & \multicolumn{2}{|c|}{$92 \pm 2$} & $92 \pm 7$ & $95 \pm 4$ & $99 \pm 5$ & $97 \pm 5$ \\
\hline 溶血終了点 & \multicolumn{2}{|c|}{$66 \pm 1$} & $73 \pm 4$ & $71 \pm 4$ & $76 \pm 3$ & $75 \pm 5$ \\
\hline 谘血幅 & \multicolumn{2}{|c|}{$44 \pm 1$} & $77 \pm 4$ & $79 \pm 4$ & $74 \pm 3$ & $75 \pm 5$ \\
\hline
\end{tabular}

表 5 凍結前後における末梢血幹細胞の性状

\begin{tabular}{cccc}
\hline & 凍結前 & 融解後EVAバッグ & 融解後KFBバッグ \\
\hline 単核球数 $\left(\times 10^{9}\right)$ & $1.33 \pm 0.30$ & $1.22 \pm 0.28$ & $1.21 \pm 0.30$ \\
単核球回収率 $(\%)$ & - & $93.5 \pm 16.9$ & $91.0 \pm 13.5$ \\
生存率 $(\%)$ & - & $93.3 \pm 3.5$ & $93.0 \pm 3.7$ \\
コロニー形成細胞回収率 $(\%)$ & - & $63.8 \pm 22.3$ & $64.0 \pm 18.4$ \\
\hline
\end{tabular}

Mean $\pm S D(n=5)$

\section{3. 細胞の凍結保存}

IIII板の凍結保存に特いて，PVCバッグは 凍結中に破損が起こるため, 融解時にはバッグ を他の容器に入れて水浴中で融解を行った。， バ ッグの破損により外部に漏れた内容液を回收し たが，最終的に血小板の回収率は低下した（表 3). しかし， KFB バッグと PVCバッグで凍 結融解後の血小板機能に有意差は認められなか った。

赤血球の凍結保存は, 日本赤十字血液センタ 一の凍結保存法が現行では PVCバッグにて - $80^{\circ} \mathrm{C}$ のフリーザーで保存することが定めら れているため 2$)$, 液体窒素温度ではなく $-80^{\circ} \mathrm{C}$ での比較を行った，凍結融解後の赤血球の性状 に拈いて，KFB バッグと PVCバッグ保存間 で有意差は認められなかった（表 4 ）.

末梢血幹細胞の凍結保存では，凍結融解後の 単核球回取率，生存率，総コロニー形成細胞回 收率は，各々 EVA バッグで $93.5 \%, 93.3 \%$,
$63.8 \%$ であるのに対して KFB バッグでは $91.0 \%, 93.0 \%, 64.0 \%$ であり，両バッグ間 で有意差は認められなかった（表 5 ）.

\section{考察}

凍結保存は凍書保護物質の添加・除去が必要 であり，その操作は熟練を要する。また，プロ グラミングフリーザー, 冷凍庫, 液体窒素など 特殊な装置が必要であり，コストがかかる，特 に凍結保存バッグはこれまで入手可能なのは数 社（ガンブロ一社製等）に限られ，洒格も高く， またその形状も取り扱う上で不便な点が多い。 実際，血漿の保存にみられるよらに PVCバッ グを凍結保存時 $\left(-80^{\circ} \mathrm{C}\right)$ でも破損の危険性 を考慮した上で使用されているのが現状であり， 血球成分の凍結保存容器として液体窒素温度に も耐えることを保証しらる凍結保存バッグの開 発が必要である.

我々がバッグ素材として選択したラミネート 
フィルムの物理的性質は，表 1 に示したように 室温よりも低温に和いて破断強度が高かった。 これは，低温に特ける樹脂の結晶化により分子 間力が增したためと考えられる。比較に用いた PVC シートは，樹脂に含まれる可塑剤が室温 では液体であるのに対して低温では固体化する ため，この傾向が顕著であった，PVC シート で作成したバッグは，液体窒素温度下ではその 柔軟性が失われてしまうため内容物の固体化に ともなら容積変化や，急激な温度変化によるス トレスに耐えることができず破損を招いてしま らが，ラミネートフィルムでは柔軟性が保持さ れることから液体空素温度に耐えらることが破 損試験の結果から証明された（表 2 ）.

液体窒素保存に牤いて，最も破損が心配され るのはバッグとチューブの接続部分であるが， $\mathrm{KFB}$ バッグはチューブの接続部分には比較的 低温特性の高いポリオレフィン系樹脂を使用し ており，凍結実験では接続部分の破損は全くみ られなかった (データ示さず).

血小板の凍結保存の結果に抽いて，PVCバ ッグと $\mathrm{KFB}$ バッグで材質の違いによる血小板 機能に与える影響はみられなかった（表 3 ）。

$\mathrm{KFB}$ バッグに用いた素材は，ガスの透過性は PVC バッグ並（表 1）であるが，可塑剤を含 まないことから可塑剤溶出の危険性はなく，直 接 $\mathrm{KFB}$ バッグにアフェレーシス P Cを採取し ても凍結操作まで短時間であれば，室温保存す ることも可能であると考える.

赤血球の凍結保存に特いても $\mathrm{KFB}$ バッグと PVC バッグ保存間で涷結融解後の赤血球の性 状に有意差は認められなかった（表 4 ）. 赤血 球の液状保存では, PVC バッグから溶出して くる可塑剤が赤血球の細胞膜の保持に役立ち溶 血の防止に効果があると考㝋られている5). 今 回の凍結保存に和いては，触解後の赤血球は全 て PVCバッグに移して再浮遊したため，この 点の差異をみることは出来なかった．凍結保存 時は PVCバッグに含まれる可塑剂自体が固体 化するため血液中に溶出することはほとんどな い上に，通常の融解・洗浄操作では，融解した 赤血球は洗浄用のバッグに移されるか連続遠心 洗浄装置にかけられて，再浮遊した赤血球は
PVCバッグに保存される.このことから，凍 結保存容器の素材が赤血球に与光る影響は実際

上ほとんどないものと考えられる。

末梢血幹細胞移植は，近年その適用が広がり つつある6)。 また，臍帯血中の幹細胞も造血幹 細胞の供給源として考兄られつつある7．いず れの移植の場合も細胞を一定期間凍結保存する ことが必須である. 表 5 に示すよらに末梢血幹 細胞の性状は， $\mathrm{KFB}$ バッグ， EVA バッグ保 存に执いて両者間で有意な差はみられなかった。

凍結保存に括いて，凍結保存温度は細胞の生 存率に大きく影響する8)。一般に保存温度が低 ければ，融解後の細胞生存率は保存期間が長く なる場合でも安定して高いといえる。凍結保存 铪器の素材は, 細胞に対して凍結中にほとんど 影響を与学ることがないと考えられるが，本研 究に沶いても血小板，赤血球，末梢血幹細胞の 凍結保存による融解後の性状は各バッグ間で有 意差は認められなかった。

\section{結論}

新しく開発した液体窒素温度に耐えうる素材 を用いた KFB バッグによる血液細胞の凍結保 存に括いて，赤血球，血小板，末梢血幹細胞の いずれも，比較に用いたバッグでの保存成績と 有意差は認められなかった。

$\mathrm{KFB}$ バッグは液体窒素温度下で破損しない ことが，素材の物理的性質及び水を充媜しての 凍結, 急激な温度変化, 落下による破損試験か ら示された。

以上のことから血液細胞の凍結保存用として 開発された $\mathrm{KFB}$ バッグは， $-80^{\circ} \mathrm{C}$ 及び液体 窒素温度での血液細胞の凍結保存に有用である ことが確認された。

\section{引用 文 献}

1）日本規格協会：JIS ハンドブック11 プラスチ ック1992，422-431，三美印刷株， 1992.

2）日本赤十字社：赤十字血液センター業務標準・ 技術部門 - 日本赤十字血液事業部，東京， 1992 .

3）高橋恒夫, 細田真理, 関口定美: フィルター飞 よる濃厚赤血球製剤からの白血球除去一Pall RC100, Pall RC50 及び Pall BPF 4 の評価 一, 医科器峨学, 62 (2) : 68-77, 1992. 
( 26 ) 医器学 Vol. 65, No. 1 (1995)

4）柴田浩二, 高橋恒夫, 茂木祐子, 細田真理, 門 脇絵美, 石田 登, 中瀬俊枝, 関口定美: ステ リセルプロセッサーの末梢血幹細胞分離及び涷 結保存への適用, 医科器械学, $63(2): 47-53$, 1993.

5) Timothy N. Estep, Robin A. Pedersen, Theresa J. Miller and Kathleen R. Stupar : Characterization of erythrocyte quality during the refrigerated storage of whole blood containing Di-(2-ethylhexyl) phtha- late, Blood, 64:1270-1276, 1984.

6) 関口定美, 高橋恒夫: 末梢血中造血幹細胞採取 の効率化の試み, 医学のあゆみ, $167: 682-$ 684, 1993.

7）高橋恒夫, 関口定美 : 七ト臍帯血中幹細胞移植 の問題点, 医学のあゆみ, $167 ： 689-691,1993$.

8）高橋恒夫：動物細胞の凍結傷害と凍害防御剤の 作用機序, 凍結保存一動物 - 植物 - 微生物(酒井 昭編), 幹倉書店. 15-23， 1987. 